\title{
OILSEEDS SECTOR OF BANGLADESH: CHALLENGES AND OPPORTUNITIES
}

\author{
M.A.M. Miah ${ }^{1 *}$ and M.R.I. Mondal ${ }^{2}$ \\ ${ }^{1}$ Agricultural Economics Division, Bangladesh Agricultural Research Institute (BARI), Gazipur-1701 \\ ${ }^{2}$ Bangladesh Agricultural Research Institute (BARI), Gazipur-1701
}

\begin{abstract}
The imports of edible oils and oilseeds are increasing year after year to fulfill the increasing demand of Bangladesh. Appropriate policy measures are needed to increase oilseed production. Therefore, an in-depth investigation was carried out to assess the challenges and opportunities in the oilseeds sector of Bangladesh. The study analyzes data generated from a sample of 1980 households spread over 11 oilseed growing districts. In addition, eleven focus group discussions (FGDs) were also conducted. The study shows that there are ample opportunities to increase both area and productivity of oilseeds because of availability of short-duration improved varieties and suitable agro-climatic conditions. Also at the production and post-harvest processing levels, there is some potential for mechanical interventions that might add to the current oilseed production processes, and allow farmers to earn more from oilseed cultivation. There are also challenges such as climate variability, competition with other crops for scarce resources, and high infestation of insects \& diseases.
\end{abstract}

Keywords: Oilseeds, challenges, opportunities, Bangladesh

\section{INTRODUCTION}

Edible oils play vital roles in human nutrition by providing calories and aiding in digestion of several fat soluble vitamins, for example Vitamin A (National Research Council, 1989). The per capita recommended dietary allowance of oil is 6 $\mathrm{gm} /$ day for a diet with $2700 \mathrm{Kcal}$ (BNNC, 1984). At least $15 \%$ (405 kcal) of the total calories must come from visible and invisible oils or fats for maintaining good health. Some oilseeds are also a source of good quality protein, vitamins, and fuel. Oilcake is also an important manure for crop production and livestock feed.

Bangladesh has to spend a huge amount of foreign exchange on imports of edible oils and oilseeds to meet the increasing demand of its population. The value of imports is increasing year after year (Figure 1). The values of imported edible oils

\footnotetext{
" Corresponding author email: monayem09@yahoo.com
} 
and oilseeds were USD1574 million and USD354 million in 2014-2015, respectively (Bangladesh Bank, 2016).

The area under oilseeds cultivation is decreasing over the years due to various economic and technical reasons. However, the area under mustard (major oilseed crop in Bangladesh) has started increasing from 2010 onwards (Miah et al., 2014). Bangladesh government has given due importance for research and development (R\&D) of oilseed crops and invests a lot for attaining self-sufficiency in edible oils. Bangladesh Agricultural Research Institute (BARI) and Bangladesh Institute of Nuclear Agriculture (BINA) have released a good number of improved varieties of oilseeds. The rate of adoption of these improved varieties at farm level is encouraging (Miah et al., 2015b; Miah et al., 2015c) and have created positive impact and saved foreign exchange for the country (Miah et al., 2015a).

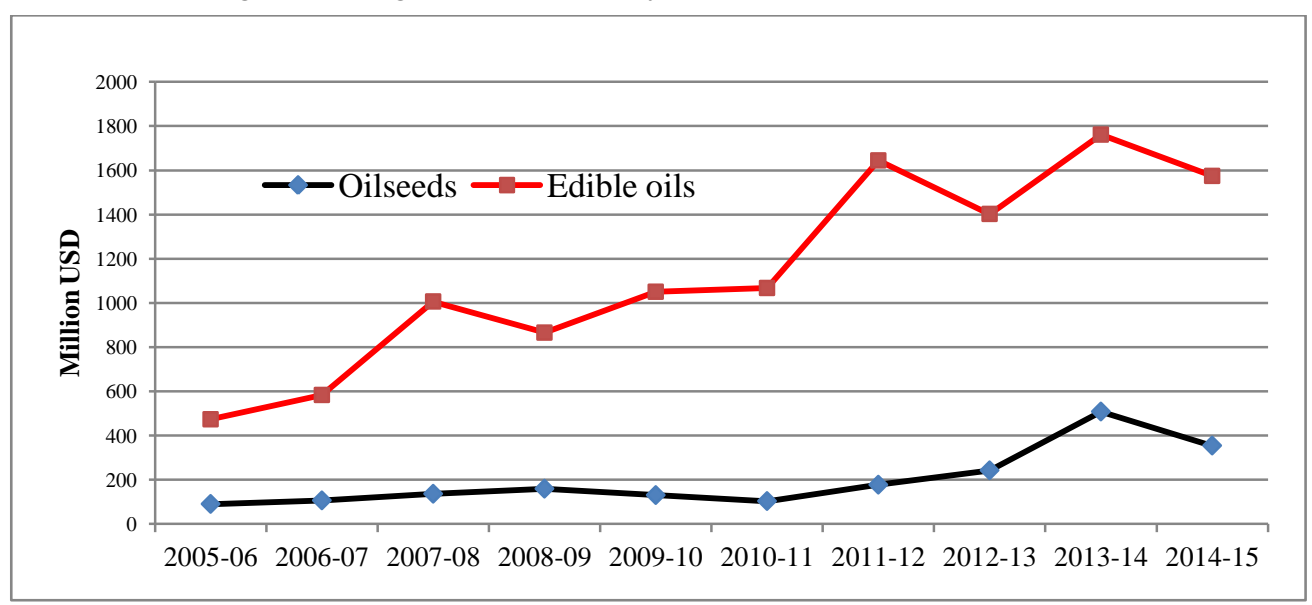

Figure 1. Trend of import value of oilseeds and edible oils

Policy-makers and research managers need overall information on oilseed crops to formulate suitable policy guidelines on oilseeds. However, an in-depth analysis is needed to explore the causes of low adoption and find out the ways for the expansion of oilseed cultivation. This study explores the challenges and opportunities in the oilseeds sector of Bangladesh.

\section{MATERIALS AND METHODS}

\section{Study area selection and sampling technique}

Four major oilseed crops namely mustard, sesame, groundnut, and soybean were taken into consideration in this study. Multi-stages sampling procedure was followed to select sample farmers. In the first stage of sampling, study areas were selected based on the area coverage of the aforesaid oilseed crops during the cropping season 2008-2009. Thus, three districts consisting high (covered $\geq 10 \%$ of the total 
area), medium (covered $<10 \%$ area), and low (covered $<5 \%$ area) growing areas were chosen for studying each type of oilseed crop. The selected districts were Manikgonj, Faridpur, Tangail, Mymensingh, Rajshahi, Pabna, Dinajpur, Noakhali, Luxmipur, Comilla, and Jessore. In the case of mustard and groundnut, the numbers of districts under high, medium and low growing areas were 3, 3, and 16, respectively, while the respective numbers were 3, 6, and 14 for sesame. For soybean, about $96 \%$ area was under Noakhali and Luxmipur. In the second stage, three suitable (in terms of data availability, accessibility, and logistic supports) Upazilas from each district were selected for each crop. Thirdly, three agricultural blocks were also selected in consultation with Agricultural Officer of the respective Upazila for collecting primary data from each oilseed growers. Finally, a total of 540 households (3 districts $\times 3$ Upazilas $\times 60 \mathrm{HHs}$ ) for each type of crop (improved \& local varieties) were randomly selected from a complete list of selected oilseed growing farmers for interview to collect primary data. Thus, a total of 2160 (540 HHs $\times 4$ crops) oilseeds cultivating farmers were interviewed for the study. But, the total sample size was only1980, because no third district has sufficient area $(>1 \%)$ under soybean cultivation to consider for the study.

\section{Data collection and study period}

Both qualitative and quantitative techniques of data collection were adopted in the present study. The researchers and trained enumerators collected data and information for this study. Data and information were collected during the period from October 2011 to October 2012. Quantitative data and information were gathered through personal interview with selected oilseed farmers using a pre-tested structured interview schedule. Qualitative technique was based on Focus Group Discussion (FGD). In total 11 FGD at Upazila level and one FGD at scientist level were conducted for this study. The focused group at Upazila level was formed with different sections of people such as Agriculture Officer (1 no.), Sub-Assistant Agricultural Officer (2 nos.), oilseed farmers (2-3 nos.), local influential persons (1-2 nos.), and oilseed traders (1-2 nos.).

\section{Analysing adoption and profitability of oilseed cultivation}

An attempt was made to estimate the adoption rate and profitability (financial and relative) of local and improved oilseed varieties in Bangladesh. The financial profitability of improved oilseeds production over their local varieties was calculated using simple accounting procedures. It was examined on the basis of gross return, gross margin and benefit cost ratio analysis. Besides, the opportunity costs of family supplied labour and cultivated land were taken into consideration in estimating total cost. Land use cost was calculated on the basis of lease value of land. In estimating relative profitability, the financial profitability of different competing crops was also estimated and compared with selected oilseed crops. Again, the costs and returns of improved oilseed variety were also compared with the respective costs and returns of local oilseed variety. Hence, data relating to input use for the production of selected 
oilseeds and their competing crops, and their market prices were collected. Besides, data on outputs and their prices were also gathered for the study.

\section{RESULTS AND DISCUSSION}

Challenges: Based on the survey studies it was observed that the challenges involved in the oilseeds sector of Bangladesh are related to climatic variability, competition with other crops, production and post-harvest management and market access. These issues are briefly discussed below.

Climate variability: Farm level information revealed that more than $12.4 \%$ mustard growing farmers, $7.2 \%$ sesame farmers, and $4.2 \%$ soybean farmers faced unsuitable weather problem during cultivation (Table 1).The temperature and rainfall pattern are very irregular in Bangladesh which is harmful for mustard and soybean production. Water logging is a problem for sesame cultivation. Flash flood during April-May in the coastal region is a problem for groundnut cultivation. Therefore, weather variability could have detrimental effects on the yields of oilseeds. Besides, Bangladesh is also facing a problem of salinity which also hinders expansion of oilseeds area (FGD, 2013).

Lack of availability of improved short-duration oilseed varieties: There is a demand for improved and short-duration oilseed varieties. Most of the mustard farmers opine that they want to cultivate boro rice just after harvesting of oilseed crops. The gap between T. Aman and boro rice cultivation is very small (80-90 days). Therefore, they need short duration varieties of mustard, groundnut, and soybean. BARI and BINA has developed a number of improved oilseed varieties, but the nonavailability of such oilseed varieties at farm level compels farmers to use local or BARI released old varieties (Figure 2). Most of the BARI released varieties of oilseeds are of longer duration that cannot be fit in the cropping pattern T. Aman Oilseeds- boro rice (FGD, 2013). Therefore, the lack of short-duration hybrids of oilseeds is also a constraint to expand oilseed area in Bangladesh. Again, the existing seed companies or NGOs working with farmers are not interested from business point of view to produce and market improved seeds of oilseeds (FGD, 2013). They usually want more profit from their business.

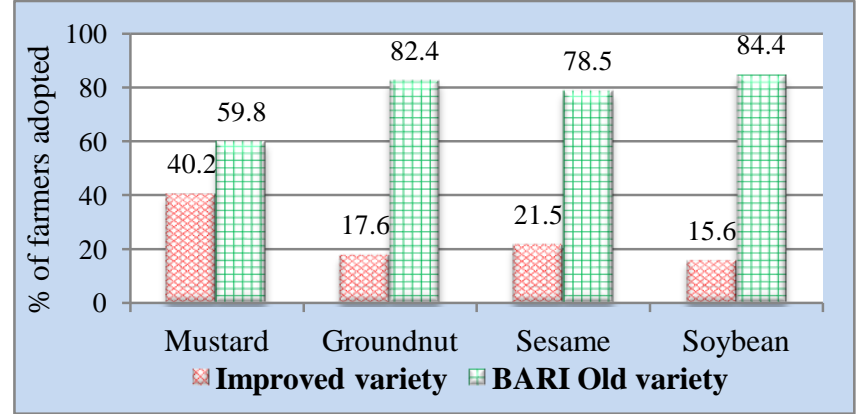

Figure 2. Overall adoptions of improved oilseeds at farm levels, 2012 
Competition with other crops: Most of the farmers in Bangladesh are poor and the main cereal food items for them are rice and wheat. They are always interested in growing boro rice in the winter season. Nevertheless, a variety of high value crops are also grown in the winter season. As a result, oilseeds have to face serious competition with these high value crops in terms of crop choice by the farmers.

Lack of stress tolerant varieties: Many areas of Bangladesh are prone to various biotic and abiotic stresses. The prominent abiotic stresses are heat, drought, water logging, and excess moisture. The water logging problem is mainly associated with Kharif- 1 oilseed production. The farmers who have low lying land normally face loss due to water logged oilseed plants. But, Bangladesh does not have suitable oilseed varieties for such situation.

Lack of short-duration rice variety: Short-duration rice variety, especially $T$. Aman or boro rice is very much important for the expansion of oilseeds cultivation in Bangladesh. They need short duration varieties of T. Aman and boro rice so that they can successfully cultivate oilseed crops in between two rice crops. But, due to the unavailability of short-duration rice varieties (i.e., BINAdhan-7, BRRIdhan-33), farmers cannot cultivate mustard at the desired level. About $40 \%$ of soybean and groundnut farmers, $26.9 \%$ mustard, and $22.2 \%$ sesame farmers have reported lack of short duration rice varieties as a crucial problem (Table 1).

Infestation of insects and diseases: With the expansion of modern variety, pest management from 'seed to seed' is getting increasing importance. Infestations of different insects and diseases are reported to be the problems in oilseed cultivation. The important insects are pod borer, jassid, stem borer, leaf eater, leaf hopper, cater pillar, and hoq moth. About 56\% soybean farmers have mentioned insect infestation problem, which followed by groundnut (43\%), sesame (37.8\%), and mustard (19.4\%) farmers.

Oilseed farmers also report various disease symptoms during oilseed cultivation. The symptoms are black spots on leaf and siliqua (pod), leaf becomes yellow or curl or white, white spot on leaf, flowers fall off, and plant becomes dry. About 20\% groundnut farmers and $13.9 \%$ mustard farmers encountered this disease problem during cultivation (Table 1).

Lack of cash and access to financial institutions: The cost of cultivation is a burden to many small and marginal farmers. They do not have enough access to state owned financial institutions due to complicated rules and regulations. Therefore, lack of liquid cash and lack of access to finance leads to inferior input purchases and improper post-harvest management resulting in low income. Usually, they borrow money from informal sources (e.g. moneylenders, friends, relatives, local traders, etc.) at very high interest rates. The moneylender's interest rate varies considerably with a mean of $103.3 \%$ with minimum $10 \%$ and maximum $240 \%$ (Mallick, 2009). The highest percentage of soybean (38.9\%) and groundnut farmers (25.9\%) expressed this as a major problem (Table 1). 
Table 1. Problems and constraints to oilseed production in the study areas

\begin{tabular}{|c|c|c|c|c|}
\hline Problem and constraint & $\begin{array}{l}\text { Mustard } \\
(n=540)\end{array}$ & $\begin{array}{c}\text { Groundnut } \\
(n=540)\end{array}$ & $\begin{array}{l}\text { Sesame } \\
(n=540)\end{array}$ & $\begin{array}{l}\text { Soybean } \\
(n=360)\end{array}$ \\
\hline 1. Lack of short duration rice variety & 26.9 & 39.8 & 22.2 & 40.8 \\
\hline 2. Incidence of insects ${ }^{\mathrm{a}}$ & 19.4 & 43.0 & 37.8 & 55.8 \\
\hline 3. Infestation of diseases ${ }^{\mathrm{b}}$ & 13.9 & 19.6 & -- & 1.9 \\
\hline 4. Foggy/unsuitable weather & 12.4 & 2.2 & 7.2 & 4.2 \\
\hline 5. Lack of cash/access to credit & 1.7 & 25.9 & 8.9 & 32.2 \\
\hline 6. Damage by birds and foxes & 8.1 & 6.3 & 9.4 & -- \\
\hline 7. Scarcity of power tiller & 0.7 & 4.1 & 1.7 & 7.5 \\
\hline 8. Lack of technical knowledge & 3.3 & 3.7 & 0.6 & -- \\
\hline 9. Marketing problem ${ }^{\mathrm{c}}$ & 9.3 & 15.4 & 1.9 & 3.3 \\
\hline 10. Other problems ${ }^{\mathrm{d}}$ & 2.8 & 19.6 & 6.9 & 28.9 \\
\hline
\end{tabular}

Note: ${ }^{a}$ Pod borer,jassid, stem borer, leaf eater, leaf hopper, cater pillar, and hoq moth.

${ }^{\mathrm{b}}$ Alternaria leaf spot, white mould on leaf, leaf becomes yellow in color, flowers are fallen off, leaf becomes white, and plant dried.

${ }^{c}$ Lack of transport facility and its higher cost, high market charge, low price of produces, lack of marketing facilities

${ }^{\mathrm{d}}$ Problems related to adulteration of fertilizers, water logging, salinity, storage, nodule formation in the stem, and lack of suitable cultivable land.

Attack by birds and animals: Oilseed farmers also faced the problems of birds and foxes. Foxes generally dig the soil beds erratically which is harmful to groundnut production. Again, birds like pigeon, crow, and Shalik were reported to be harmful to mustard and sesame crops (Table 1).

Lack of availability of power tiller: Most of the tillage operations in the study areas are done by power tiller (PT). The well-off farmers generally buy PT for their own use as well as use as custom hiring basis. In the peak period of cultivation (generally winter season), some small and marginal oilseed farmers cannot plough their lands timely due to lack of availability of PT (Table 1).

Lack of proper technical knowledge: Although technical knowledge on planting time, seed rate, plant spacing, fertilization, irrigation plays a significant role in getting higher seed yield, many farmers still are not aware of the improved methods of oilseed cultivation leading to lower yield. They cultivate oilseeds based on their experience because they have no formal training on oilseed cultivation. Lack of oilseed related technical knowledge dissemination to oilseed farmers is also a problem (Table 1). 
Marketing: A small number of oilseed farmers have also mentioned marketing problems. The major problem of oilseed marketing is the lack of transports facilities. Owing to this problem, they sometimes are compelled to sell their produces at farm gate and at the local market at a low price. Sometimes, they cannot take advantage of the higher prices prevailing at the distant markets due to lack of transportation and the higher cost of transports. The other problems observed are higher marketing charges demanded by lease holders, lower price of the produces, and inadequate marketing facility (Table 1).

Farmers' interest: The sample farmers were asked to mention the possibility of expanding their cultivated area for improved oilseed crops. Owing to higher profitability and assured markets of oilseeds, most farmers are interested to cultivate oilseed crops in future. In the case of improved variety adopters, 92.63\% groundnut farmers and $51.78 \%$ mustard farmers have shown interest to increase oilseed cultivation in the next year. In the case of non-adopters, $85.53 \%$ soybean farmers and 46.63 mustard farmers have interest to expand their cultivable area (Table 2). They mentioned various reasons behind their eagerness to increase oilseed cultivation in future. These include higher yield, good price of the produces, low cost but high profit, easy cultivation, less labour, and available lands for oilseed cultivation.

Table 2. Willingness of farmers to increase oilseed cultivation in the next year

\section{Opportunities}

The opportunities exist in oilseeds sector are related to research capacity, availability of input, availability of production technology, profitability, farmers' interest, and extension facilities. All these issues are briefly discussed below. 
Suitability and availability of lands for oilseeds cultivation: Suitable land for growing a variety of crops including oilseeds is a gift of nature in Bangladesh. Most of the areas of Bangladesh are suitable for rice and oilseeds cultivation. Huge potential lies in areas under fallow i.e., after T. Aman harvest, Char (0.82 million ha), low-lying, dried-up riverbeds, and saline (0.85 million ha) areas of Bangladesh, where oilseeds can be grown successfully (Baniket al., 2011). In different parts of Bangladesh (e.g. Comilla, Manikgonj, Sherpur, Jamalpur, Netrokona, Tangail, Dinajpur, etc.), a huge amount of lands are kept fallow after T. Aman harvest. These fallow lands can be easily used by growing short-duration improved mustard. Char areas and dried-up riverbeds can also be utilized by growing different crops including different oilseeds (Financial Express, 2012). The major cropping pattern found in most of the coastal areas is T. Aman-Fallow-Fallow. Salt tolerant groundnut varieties can be grown in these coastal areas successfully. However, if the aforesaid potential areas can be brought under oilseeds cultivation, the country can fulfill its increasing demand by producing huge amount of oilseeds.

Dissemination of promising oilseed varieties: Technology related to oilseed cultivation has been changed to some extent due to the efforts of BARI and BINA scientists. BARI has developed some good varieties of mustard for farm level cultivation. Among these varieties, BARImustard-14 and -15 are reported to be very much promising. These two varieties are good yielder (1.4-1.6 tha $\left.{ }^{-1}\right)$ and shortduration (75-85 days). BINA has also developed three improved varieties of mustard (i.e., Agrani, Binasarisha-3 \& -4) which are high yielding (1.75-2.50 $\left.\mathrm{t} \mathrm{ha}^{-1}\right)$ and shortduration (83-85 days). The production of mustard can be increased manifolds without increasing its area, by replacing Tori-7 and MaghiSarisa (local variety) with these high yielding varieties. Among short duration varieties, BARI JhinghaBadam, BINAchinabadam-2, and BINAchinabadam-3 are potential varieties for farm level cultivation. BARI/BINA has also developed improved varieties of sesame that need to be disseminated. Therefore, a vast opportunity exists to popularize these improved oilseed varieties among farmers.

Higher productivity of improved oilseeds: Higher productivity is one of the major strengths of BARI and BINA released improved oilseed varieties in Bangladesh. The yield advantage of improved varieties of oilseeds ranged from 5-49\% (Figure 3).

Higher profitability: The cultivation of improved oilseeds is highly profitable to the farmers (Table 2). The profitability of improved oilseeds is much higher than that of its traditional variety. It is also reported that the profitability of improved mustard cultivation is higher compared to its competing crops like cabbage, carrot, maize, onion, potato, and wheat. Again, the profitability of improved groundnut cultivation is much higher than that of its competing crops, such as pulses, chilli, brinjal, wheat and onion. Sesame cultivation is also more remunerative than Aus rice cultivation (Miah et al. 2015d). Dey et al. (2013) analysed the profitability of mustard production and estimated average net return and BCR as Tk.14,649/ha and 1.36 
respectively. Kawser (1993) estimated the net return and BCR of groundnut cultivation Tk. 2,030/ha and 1.11, respectively. Again, Akter et al. (2010) found soybean as the second most profitable crop in Noakhali and Laxmipur districts. Thus, there is an ample opportunity to expand oilseeds cultivation in Bangladesh.

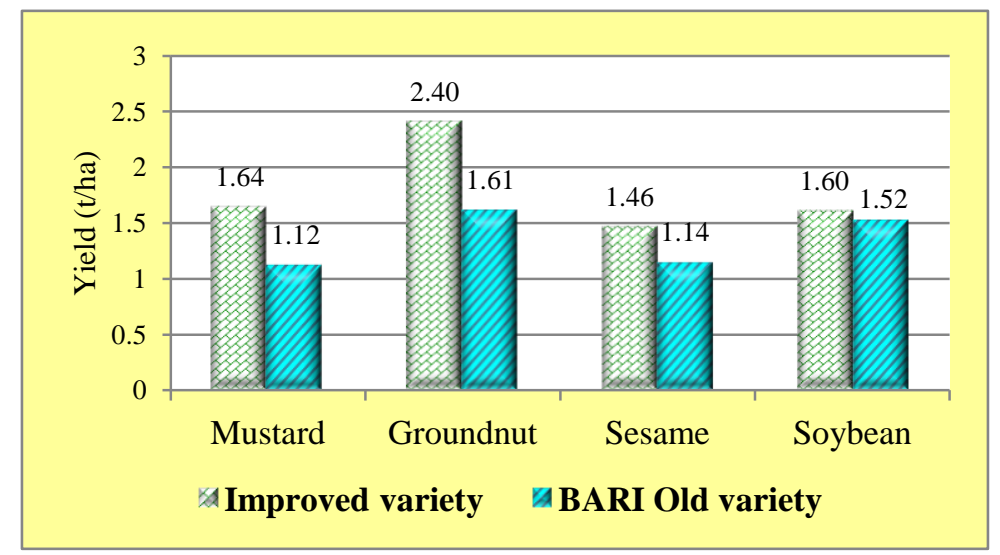

Figure 3. Yield of local and improved oilseeds at farm levels

Introduction of mechanized seeder and raised bed technology: There is an ample scope of introducing mechanized seeder and raised bed technology in oilseed, especially soybean, groundnut and sesame cultivation to increase the yield. The turnaround period between T. Aman rice and oilseed crops is very short. After ploughing the land, farmers can use mechanized seeder for sowing soybean, sesame, and groundnut seed quickly. The system of sowing seeds on raised bed is relatively new in Bangladesh and is very much useful for sesame and groundnut cultivation (FGD, 2013

Improved post-harvest management practices: Improved post-harvest anagement practices are very much important especially for groundnut, sesame and soybean. Many oilseed farmers experience low yield due to poor storage of seeds and lack of knowledge on post-harvest practices. Providing adequate knowledge on post-harvest management practices to the farmers and creation of adequate storage facility both can play an important role in this aspect (FGD, 2013).

Private sector involvement: Private sector in Bangladesh is interested in promoting hybrid seeds of different crops (e.g. maize, wheat, rice, vegetables, etc.). Currently, ACI Seed and CCDB have extended their hands to promote BARImustard 14 and 15 varieties among their stakeholders. Besides, the oilseed scientists of BARI have opined that higher demand for branded mustard oil is being created by the expansion of manufacturing capacities of the private oil mills in the country (FGD, 2013). Therefore, there are ample opportunities for private sectors for doing business with different improved varieties and products of oilseeds. 
Table 3. Profitability of improved oilseeds cultivation in the study area

\begin{tabular}{|c|c|c|c|c|}
\hline Particular & $\begin{array}{l}\text { Mustard } \\
(n=217)\end{array}$ & $\begin{array}{l}\text { Groundnut } \\
(n=95)\end{array}$ & $\begin{array}{l}\text { Sesame } \\
(n=425)\end{array}$ & $\begin{array}{c}\text { Soybean } \\
(n=56)\end{array}$ \\
\hline Varieties cultivated & $\begin{array}{l}\text { BARI Sarisa-9, - } \\
\text { 14, -15, -16, \& } \\
\text { BAU Sampad }\end{array}$ & $\begin{array}{c}\text { BARI } \\
\text { Chinabadam-5, -6, } \\
\text { \& Dhaka No. } 2\end{array}$ & $\begin{array}{l}\text { BARI Til-3, }-4, \\
\text { \&BINA Til-1 }\end{array}$ & $\begin{array}{c}\text { BARI Soybean- } \\
5, \&-6\end{array}$ \\
\hline 1. Yield $\left(\mathrm{kg} \mathrm{ha}^{-1}\right)$ & $1,641.26$ & $2,398.98$ & $1,458.30$ & $1,598.30$ \\
\hline 2. Farm gate price $\left(\mathrm{Tk} \mathrm{kg}^{-1}\right)$ & 46.5 & 59.97 & 37.0 & 29.6 \\
\hline 3. Gross return $\left(\mathrm{Tk} \mathrm{ha}^{-1}\right)$ & 80,105 & 146,248 & 56,796 & 48,171 \\
\hline Main product & 76,319 & 144,934 & 54,333 & 47,475 \\
\hline By-product & 3,786 & 1,314 & 2,463 & 696 \\
\hline 4. Total variable cost $\left(\mathrm{Tk} \mathrm{ha}^{-1}\right)$ & 23,496 & 36,028 & 24,527 & 26,669 \\
\hline 5. Total fixed cost $\left(\mathrm{Tk} \mathrm{ha}^{-1}\right)$ & 27,750 & 26,020 & 18,391 & 17,741 \\
\hline 6. Total cost $\left(\mathrm{Tk} \mathrm{ha}^{-1}\right)(4+5)^{*}$ & 51,246 & 62,048 & 42,918 & 44,410 \\
\hline 7. Gross margin $\left(\mathrm{Tk} \mathrm{ha}^{-1}\right)(3-4)$ & 56,609 & 110,220 & 32,269 & 21,502 \\
\hline 8. Net return $\left(\mathrm{Tkha}^{-1}\right)(3-5)$ & 28,859 & 84,200 & 13,879 & 3,761 \\
\hline 9. Net return $\left(\mathrm{Tk} \mathrm{ha}^{-1}\right)$ & 3,895 & 11,363 & 1,873 & 508 \\
\hline \multicolumn{5}{|l|}{ 10. Benefit cost ratio } \\
\hline Over variable cost $(3 \div 4)$ & 3.41 & 4.06 & 2.32 & 1.8 \\
\hline Over total cost $(3 \div 5)$ & 1.56 & 2.36 & 1.32 & 1.1 \\
\hline
\end{tabular}

Note: 1 acre $=3$ bigha $=100$ decimal; *total cost includes the rental value of land and cost of family supplied labour

There are ample opportunities to create value addition through promoting mustard oil and various food items based on sesame and groundnut in case of assured markets. There is also a good demand for soya foods in the urban markets. Therefore, promotion of the production and consumption of different types of soybean-based products can create value addition at both producer and national levels.

Groundnut is being used as an important ingredient of Chanachur in many food products companies. Mustard oils are marketed in different brand names by different companies in Bangladesh. Soybean is being used by some companies for preparing soya foods. Besides, the cultivation of groundnut requires a higher amount of cash (Tk. 57,332/ha) compared to other oilseed crops. Hence, there is an opportunity for the state authorities to promote contract farming systems. This will enable farmers to link with traders/companies who can provide them with technical knowledge regarding oilseeds production, access to larger buyers, and credit to buy inputs (FGD, 2013).

\section{CONCLUSIONS AND RECOMMENDATIONS}

An in-depth investigation has been done to explore the current challenges and opportunities existed in the oilseeds sector of Bangladesh. The study has identified different strengths and opportunities in the oilseeds sector, such as research 
capability, good varieties, higher profitability, farmers' interest, existing extension services, availability of potential areas, and private sector involvement. Also at the production and post-harvest processing levels, there are some potential for mechanical interventions that might add value to current oilseed production processes, and allow poor farmers to earn more income from oilseed cultivation. In addition, there are also some challenges in oilseeds sector which are climate variability, high competition with other crops, lack of improved variety, and insect\& disease infestation. Overall findings suggest that the opportunities existed in the oilseed sector are outweigh the challenges involved in this sector.

The following recommendations are made to enhance oilseed production for attaining self-sufficiency in Bangladesh.

- Existing improved short-duration rice and oilseed varieties should be disseminated among the farmers.

- The improved quality seeds of oilseeds and rice should be made available at farm level.

- Existing extension services should be strengthened for developing farmerextension personnel linkage.

- Potential areas should be brought under oilseed cultivation as soon as possible.

- Private sectors should be involved in oilseed production and value addition.

- Oilseed research and development should be strengthened in collaboration with international research institutes for developing improved oilseed varieties.

- Regular training programme should be conducted for farmers and extension personnel.

- Institutional credit facilities may be provided to oilseed farmers.

\section{REFERENCES}

Akter, M., Miah, M.A.M., Khurram, M.M.H., Rahman, M.S. and Alam, Q.M. 2010. Economic feasibility of soybean production in some selected areas of Bangladesh. Bangladesh Journal of Agricultural Research, 35(4): 561-571

Banik, B.R., Amiruzzaman, M., Rahman, M.M. and Khaldun, A.B.M. 2011. Maize improvement in Bangladesh, Paper presented in $11^{\text {th }}$ Asian Maize Conference 2011, Beijing, China

Bangladesh Bank, 2016. Category wise import payments, Statistics Department, Bangladesh Bank, Dhaka, Bangladesh. Retrieved 15 August, 2016 from www.bb.org.bd/econdata/import/categoryimp.php

BNNC, 1984. Nutrition Policy and Programme for Bangladesh, Bangladesh National Nutrition Council, 19/1 Rasulbagh, Mohakhali, Dhaka. P.70-79

Dey, N.C., Bala, S.K., Islam, A.K.M.S. and Rashid, M.A. 2013. Sustainability of groundwater use for irrigation in northwest Bangladesh. National Food Policy Capacity 
Strengthening Programme (NFPCSP), Food Planning and Monitoring Unit (FPMU), Ministry of Food, FAO-Bangladesh, Dhaka

FGD, 2013. Focused group discussion with extension personnel of different upazilas and the scientists of Oilseed Research Centre, Bangladesh Agricultural Research Institute (BARI), Gazipur.

Financial Express, 2012. Char land brought under crops cultivation in Gaibandha. $6^{\text {th }}$ December, 2012; Crop harvest ends in dried-up riverbeds, Chars lands, $4^{\text {th }}$ June 2012. Retrieved 12 February, 2013 from http://www. thefinancialexpress-bd.com/index.php?

Kawser, M.K. 1993. A comparative analysis of sweet potato and groundnut cultivation in a selected area of Kishoregonj district with special reference to small farmers. M.S. (Agril. Econ.) diss. Bangladesh Agricultural University (BAU), Mymensingh, Bangladesh

Mallick, D. 2009. Microfinance and moneylender interest rate: evidence from Bangladesh. Research Monograph Series No. 42, Research and Evaluation Division, BRAC, 75 Mohakhali, Dhaka 1212, Bangladesh. http://research.brac.net/monographs/microfinance_moneylender_m42.pdf

Miah, M.A.M., Rashid, M.A. and Shiblee, S.A.M. 2014. Assessment of socioeconomic impacts of oilseed research and development in Bangladesh. Research report submitted to PIU-BARC, BARC complex, Farmgate, Dhaka-1215.

Miah, M.A.M., Shiblee, S.A.M. and Rashid, M.A. 2015a. Socioeconomic impacts of oilseeds research and development in Bangladesh. Bangladesh Development Studies, 38(1):1-31

Miah, M.A.M., Afroz, M.S., Rashid, M.A. and Shiblee, S.A.M. 2015b. Factors affecting adoption of improved sesame technologies in some selected areas in Bangladesh: An empirical study. The Agriculturist, 13(1):140-151

Miah, M.A.M., Afroz, M.S., Rashid, M.A. and Shiblee, S.A.M. 2015c. Factors affecting the adoption of improved varieties of mustard cultivation in some selected sites of Bangladesh. Bangladesh Journal of Agricultural Research, 40(3): 363-379

Miah, M.A.M. and Rashid, M.A. 2015d. Profitability and comparative advantage of oilseed production in Bangladesh. Bangladesh Development Studies, 38 (3): 35-54

National Research Council, 1989. Diet and Health: Implications for Reducing Chronic Disease Risk. Washington, DC: The National Academies Press, 1989. doi:10.17226/1222 